DOI: $10.12731 / 2227-930 X-2018-2-9-21$

UDC 332.12

\title{
STRATEGIC MANAGEMENT OF COMPETITIVE AGRIBUSINESS ORGANIZATIONS MODEL
}

\section{Altukhova L.A., Semko I.A.}

The article is devoted to solving the task of developing a model of strategic management agribusiness organizations, which should become an important element affecting the competitiveness of business entities. Obviously, one of the most important directions for further stable economic growth is the improvement of management techniques aimed at solving the problems of increasing the competitiveness of enterprises.

Several provisions of the article are devoted to clarifying the nature and content of the competitive strategy, developing stages of strategic management and identifying a set of measures to implement strategies in organizations. The importance of information support as the initial stage of building an effective management system of the organization which is focused on the formation and maintenance and stabilization of competitiveness. The emphasis was placed on the need of agricultural production in the development of the grows strategy and its detailed elaboration in functional strategies from the perspective of ensuring competitiveness in the long term conditions.

Purpose is the development of scientific and methodological approaches to building a model of strategic management of competitive agricultural organizations.

Methodology in the article used system and situational approaches, as well as methods such as abstract-logical and comparative analysis.

Results: The article has a research character that is based on the analysis of theoretical aspects and practical problems of strategic management, proposed an approach how to build strategic management 
model in the organization which is focused on the formation of competitive detailing advantages that allows to create specific recommendations and determine the tools for their implementation.

Practical implications. The implementation of the proposed model of strategic management focused at increasing of the economic entities competitiveness based on the management of agricultural enterprises will help ensure their stable development in the long term.

Keywords: strategic management; competitiveness; competitive strategy; functional strategies.

\section{МОДЕЛЬ СТРАТЕГИЧЕСКОГО УПРАВЛЕНИЯ КОНКУРЕНТОСПОСОБНЫМИ ОРГАНИЗАЦИЯМИ АГРОБИЗНЕСА}

\section{Алтухова Л.А., Семко И.А.}

Статья посвящена решению задачи разработки модели стратегического управления организачиями агробизнеса, которая должна стать важным элементом, влияющим на конкурентоспособность субъектов хозяйствования. Очевидно, что одним из важнейших направлений дальнейшего стабильного роста экономики является совершенствование приемов управления, направленное на решение проблем повышения конкурентоспособности предприятий.

Ряд положений статьи касается вопросов уточнения сущности и содержания конкурентной стратегии, разработки этапов стратегического управления и определения комплекса мероприятий по реализачии стратегий в организачиях. Обоснована важность информационного обеспечения, как исходного этапа построения эффективной системы управления организачией ориентированной на формирование и поддержание конкурентоспособности. Сделан акцент на необходимости учета особенностей аграрного производства при разработке стратегии развития и ее детализащии в функииональных стратегиях с позищий обеспечения конкурентоспособности в долгосрочной перспективе. 
Цель - разработка научно-методических подходов к построению модели стратегического управления конкурентоспособными сельскохозяйственными организациями.

Метод или методология проведения работы: в статье использовались системный и ситуационный подходы, а также такие методы, как абстрактно-логический и сравнительного анализа.

Результаты. Статья имеет исследовательский характер, выражающийся в том, что на основе анализа теоретических аспектов и практических проблем стратегического управления предлагается подход к построению в организачии модели стратегического управления направленной на формирование конкурентных преимуществ и осуществляется его детализаџия, позволяющая сформировать конкретные рекомендации и определить инструментарий по их реализачии.

Область применения результатов. Реализация предложенной модели стратегического управления направленной на повымение конкурентоспособности хозяйствуюших субъектов в практике управления аграрными предприятиями будет способствовать обеспечению их стабильного развития в долгосрочной перспективе.

Ключевые слова: стратегическое управление; конкурентоспособность; конкурентная стратегия; функииональные стратегии.

\section{Introduction}

Modern economic and political conditions, characterized by a certain level of instability and necessity for further reliable provision of import substitution for agro-food products, raise increased requirements for the construction of the management system for agribusiness entities [2, 4, 6, 19, 21]. Strategic management oriented for increasing the competitiveness of the organization will allow agribusiness entities to maintain their positions on the market with the similar organizations and provide the sustainable positions in the food market [16].

This problem research relevance is explained not only by the practical importance, but also by the necessity of theoretical developments in the field of increasing the competitiveness of agricultural enterprises 
by realizing the advantages of strategic management [3] as one of the generally proposed tools for effective business development.

A lot of studies are devoted to various problems and aspects of strategic management, including also agricultural business. Particular interest represent the model that considers the strategic management of an enterprise, which combine five components: a strategic leader, strategic management methodology, right business structure, right business culture, recruiting and coaching staff programs [8]. However, this model focuses only for the strategy implementation phase and does not concern the issues of their construction.

Other researchers consider strategic management model as a set of functional strategies [26]. These approaches do not cover the characteristics of one of the most important factor of the strategic management of the enterprise - the external environment. In this aspect, most important interest represent the model that include the following: development and implementation of the grows strategy and behavior in the external sphere; development and implementation of the strategy for the product advertising by the organization; development and implementation staff promotion strategy [5,9]. At the same time, these studies do not pay enough attention to issues of ensuring the organization competitiveness. From the perspective of this study, we should turn to the approach [10], according to which the strategic management of an enterprise is carried out in the interconnection of its potential, strategy and competitiveness, but at the same time it does not sufficiently take into account the specific characteristics and requirements of different economy sectors, and particularly agribusiness sphere.

Taking into account this stage of modern science, we concluded that it is necessary to develop a model of strategic management for agribusiness entities focused on increasing competitiveness, which are the purpose of this study.

In accordance with this goal, we have certain tasks:

- identification of "best practices" among existing models of strategic management of organizations;

- taking into account the specifics of the agricultural business; 
- the definition of the strategic management stages of agricultural enterprises;

- assessment of the prospects for implementing the proposed model.

\section{Method of research}

To solve these problems, it is necessary to use systematic and situational approaches, as well as methods such as abstract-logical and comparative analysis. Methodology of strategic management - a set of methods, principles and methods of strategic decision-making and their practical implementation in order to achieve the goals that allow the company to optimally use the existing potential and remain receptive to the requirements of the external environment.

\section{Result of the study}

Focusing on the objectives of the strategy for the development of agricultural enterprises, and correlating them with the tasks of ensuring the competitiveness of organizations, we propose an approximate model of strategic management, which includes the following blocks: information support, formation of business development strategy, implementation of competitive strategy, management and monitoring of strategy implementation.

The initial stage of the proposed model is the process of forecasting the possibilities for the development of agricultural enterprises. The information base is the basis for obtaining the initial data for calculating the prognosis of development [14]. It consists of a certain set of arrays, which forms the necessary archival, normative, planned and operational information on the state of agricultural production [20]. We consider it expedient to conduct analysis in three main areas: trends and forecasts of national and world development; trends in the development of the industry and industrial markets [12]; competitive conditions for the operation of the business [17].

The result of the strategic planning process is the development of a strategy. At the same time, the preparation, adoption and implementation of the strategy can be viewed as an information process that, 
regardless of the level of the strategic decision, is built on a similar algorithm that is cyclical:

1. Collecting and processing by experts in strategic management of information on the state of the subject of agribusiness and the external environment of its functioning [24, 25].

2. Analysis of the received information and development of a strategic decision.

3. Corrective effect of economic activity of an agricultural enterprise.

The effectiveness of the developed strategy will largely depend on the reliability of the information obtained in the process of analysis as internal factors of the agricultural organization and external forces.

The formation of an analytical database should take place with the use of modern information technologies. In addition, we should use the tool for converting information based on statistical and economicmathematical models [13].

Assessing the prospects for improving information support for strategic management, priority should be given to the development of information networks and the use of information placed in them. Therefore, it is critical to create a single information space that combines all entities involved in agrarian production into one information network, as well as a set of tools that can solve the problems of creating an information center that provides all agricultural enterprises with the necessary information. The service of such information support should include structures that provide advice to commodity producers [22,23]. Thus, the system of information and consulting services should contribute to the development of the strategic management process, which is in the same time leads to an increase in the competitiveness of agricultural enterprises.

Knowing of the necessary and sufficiently reliable information for the implementation of the strategic planning process, agricultural organizations are developing their own strategy, which includes an overall competitive strategy that is detailed in the functional strategies.

The competitive strategy determines the activity of the enterprise as a whole and ensures the consistency and efficiency of various types of activity of diversified entrepreneurial structures $[1,15]$ in conditions of 
high dynamic external environment. The activities of agricultural enterprises are multi-sectorial, that is why the main objective of the strategy is to identify areas of activity in which most of the existing assets should be invested. The main objective of this strategy is the internal organizational distribution of resources, based on the analysis of current trends and prospects for the organization development [11]. Regard on this, in our opinion, the competitive strategy of agribusiness entities should include strategic directions of the development for crop and livestock sectors that determine the prospects for the development of the company's business units. On development stage of the strategy, it is necessary to take into account which tools of business competition will apply in a particular product market, which channels of product realization are the most preferable, how to improve the production technology, etc.

Detailization of the directions for development of agricultural enterprises is reflected in functional strategies. These include production, marketing, financial, human resource development [18] and other strategies. The purpose of these strategies is the coordinated activity of structural units ensuring the implementation of a competitive strategy, which is impossible without adequate and timely provision of resources.

\section{Discussion}

Implementation of the developed strategy depends on many factors: timely and complete provision of resources, willing of management to implement development programs, personnel's interest in performing labor operations, etc. Without observing the necessary organizational requirements, no one, even the most competently developed strategy, cannot be implemented.

The process of managing and monitoring the implementation of the strategy is complex in any organization, and in agricultural especially. Especially, this is connected with the risks of unfavorable climatic condition, as well as the specificity of working with living organisms [7].

Evaluation of the effectiveness of the strategy may be carried out on the basis of an analysis of the competitiveness of agribusiness organizations. Competitiveness is the result of rational management and it can 
be assessed, taking into account the factors of the enterprise's provision with the necessary resources and the extent of their use.

Implementation of the proposed model can be carried out by stages, depending on the existing overall management system.

\section{The conclusion.}

The advantage of the proposed model is its sectorial adaptation, since the central link in the development of a competitive strategy is the consideration of trends and prospects in crop production and livestock breading, which is especially important in the context of import substitution. Despite the complexity of the use of strategic management tools in agricultural enterprises, the realities of the modern Russian economy testify about the need for full-scale implementation of this mechanism in the management processes of agricultural product producers. Since it is impossible to ensure competitiveness in agricultural commodity markets, focusing on short-term goals, without taking into account the macro-economy development trends.

\section{References}

1. Ivanova A.R., Chernikova L.I., Rogacheva E.N., Lobanova M.V. Modelirovanie proizvodstvennykh protsessov i razvitie informatsionnykh sistem [Simulation of production processes and the development of information systems]. 2012, pp. 189-191.

2. Altuhova L.A., Semko I.A. Russian business. 2009. № 3-2, pp. 79-85.

3. Altuhova L.A., Semko I.A. V mire nauchnykh otkrytiy [Siberian Journal of Life Sciences and Agriculture]. 2012. № 3, pp. 175-189.

4. Bunkovskij D.V. Management issues. 2016. № 3, pp. 53-60.

5. Vihanskij O.S., Naumov A.I. Menedzhment [Management]. M.: Master, 2014. 576 p.

6. Golubyatnikova M.V., Kurbanov A.H. Regional agricultural systems: Economics and sociology. 2015. № 1. p. 6.

7. Zhuravleva E.V., Fursov V. Siccitate ut de periculo factores in oeconomia planta industria in Russian Federation. The achievements of science and technology of APC. 2016. Vol. 30. №. 9, pp. 88-90. 
8. Zabelin P.V., Moiseeva N.K. Osnovy strategicheskogo upravleniya [The fundamentals of strategic management]. Moscow. Marketing, 2007. 86 p.

9. Levushkina S.V., Semko I.A. Polythematic networked electronic scientific journal of Kuban state agrarian University. 2014. No. 102, pp. 370-381.

10. Lyukshinov A.N. Strategicheskij menedzhment [Strategic management]. Moscow: Intel-Synthesis, 2013. 375 p.

11. Markova V.D. Region: Economics and sociology. 2017. N 2, pp. 326-347.

12. Metodicheskoe obespechenie provedeniya nauchnyh issledovanij ehkonomicheskih problem razvitiya APK Rossii [Methodological support of scientific research of economic problems of development of the agroindustrial complex of Russia]. Altukhov A.I. (ed). Moscow. Fund "the Personnel reserve", 2016. 543 p.

13. Tsymbalenko T.T., Baidakov A.N., Tsymbalenko O.S. Metody matematicheskoj statistiki v obrabotke ehkonomicheskoj informacii [Methods of mathematical statistics in the processing of economic information]. Tsymbalenko T.T. (ed). Moscow; Stavropol, 2007. 200 p.

14. Nikitenko E.G. Obosnovanie prognoznyh scenariev razvitiya zernovogo proizvodstva [Justification of the forecast scenarios for the development of grain production]. Stavropol, 2012.

15. Svistunova I.G. Aktual'nye problemy razvitiya agrobiznesa $v$ usloviyah modernizacii ehkonomiki [Actual problems of agribusiness development in the conditions of economic modernization]. Proceedings of the International scientific-practical conference. Stavropol, 2012, pp. 143-145.

16. Semko I.A., Altukhova L.A. Science of Krasnoyarsk [Siberian Journal of Economics and Management]. 2017. Vol.6. № 1-3, pp. 75-79.

17. Semko I.A., Altukhova L.A. Ars complexus aestimationem gradu aemulationes pro rusticarum negotium structurae. Russian business. 2011. №. 10-1, pp. 125-131.

18. Sergienko E.G., Korshikova M.V. Economic and information problems of the region: assessment, trends, prospects. 2016, pp. 240-242.

19. Ushachev I.G. AIC: economy, management. 2015. № 1, pp. 3-17.

20. Chernikova L.I., Gurova V.I. Sushchnost'resursnogo potenciala predpriyatiya [Economic and information aspects of the region: theory and 
practice. International scientific-practical conference]. Stavropol. 2015, pp. 257-258.

21. Epstein D.B. Rate augmentum prices cibum sibi et incrementum domesticis agricultura. Nikon readings. 2017. № 22, pp. 45-48.

22. Agalarova E.G., Kurennaya V.V., Levushkina S.V., Miroshnichenko, R.V. Program development of small and medium enterprises in Stavropol region of the Russian federation. International Journal of Economics and Financial Issues, 2016, 6(2), pp. 151-157.

23. Bannikova N.V., Baydakov A.N., Vaytsekhovskaya S.S. Identification of strategic alternatives in agribusiness. Modern Applied Science. 2015. V. 9. № 4, pp. 344-353.

24. Ivolga A. G., Levushkina S.V., Varivoda V. S., Elfimova J. M. Modeling of small and medium enterprises' sustainable development. Espacios, 2017, Vol. 38 (№33).

25. Kostyuchenko T.N., Sidorova D.V., Eremenko N.V., Chernikova L.I. Insurance as a tool for managing risks in agriculture. Mediterranean Journal of Social Sciences. 2015. V. 6. № 5, pp. 220-228.

26. Safiullin M.R., Safiullin L.N., Samigullin I.G. Model of management of competitiveness of a machine-building complex. World Applied Sciences Journal. 2013. № 13, pp. 212-216.

\section{Список литературы}

1. Актуальные проблемы предпринимательства / Иванова А. Р., Черникова Л.И., Рогачева Е.Н., Лобанева М.В. // Моделирование производственных процессов и развитие информационных систем. 2012. C. 189-191.

2. Алтухова Л.А., Семко И.А. Принципы обеспечения конкурентоспособности предпринимательских структур в аграрном секторе // Российское предпринимательство. 2009. № 3-2. С. 79-85.

3. Алтухова Л.А., Семко И.А. Основные составляющие комплексного механизма стратегического управления организацией // В мире научных открытий. 2012. № 3. С. 175-189.

4. Буньковский Д.В. Импортозамещение в российской экономике: пер-спективы развития отечественных производств продовольствия // Вопросы управления. 2016. № 3. С. 53-60. 
5. Виханский О.С., Наумов А.И. Менеджмент. М.: Магистр, 2014. $576 \mathrm{c}$.

6. Голубятникова М.В., Курбанов А.Х. Состояние и проблемы обеспечения продовольственной безопасности России в современных геополитических условиях // Региональные агросистемы: экономика и социология. 2015. № 1. С. 6.

7. Журавлева Е.В., Фурсов С.В. Засуха как один из факторов риска в экономике растениеводства Российской Федерации // Достижения науки и техники АПК. 2016. Т. 30. № 9. С. 88-90.

8. Забелин П.В., Моисеева Н.К. Основы стратегического управления. М.: Маркетинг, 2007. 86 c.

9. Левушкина С.В., Семко И.А. Особенности влияния компонентов внешней и внутренней среды на деловую активность организации // Политематический сетевой электронный научный журнал Кубанского государственного аграрного университета. 2014. № 102. C. 370-381.

10. Люкшинов А.Н. Стратегический менеджмент. М.: «Интел-Синтез», 2013. $375 \mathrm{c}$.

11. Маркова В.Д. Ценностные ориентиры в концепции стратегического управления: анализ опыта российских высокотехнологичных компаний // Регион: экономика и социология. 2017. N 2. С. 326-347.

12. Методическое обеспечение проведения научных исследований экономических проблем развития АПК России / Под ред. А.И. Алтухова. М.: Фонд «Кадровый резерв», 2016. 543 с.

13. Методы математической статистики в обработке экономической информации / Т.Т. Цымбаленко, А.Н. Байдаков, О.С. Цымбаленко и др.; под ред. проф. Т.Т. Цымбаленко. М.: Финансы и статистика; Ставрополь: АГРУС,2007. 200 с.

14. Никитенко Е.Г. Обоснование прогнозных сценариев развития зернового производства: Дис... к. эк. наук. Ставрополь, 2012.

15. Свистунова И.Г. Актуальные проблемы развития агробизнеса в условиях модернизации экономики // Сборник научных трудов по материалам Международной научно-практической конференции. Ставрополь, 2012. С. 143-145. 
16. Семко И.А., Алтухова Л.А. Факторы обеспечения конкурентоспособности организации // Наука Красноярья. 2017. Т. 6. № 1-3. С. 75-79.

17. Семко И.А., Алтухова Л.А. Методика комплексной оценки уровня конкурентоспособности сельскохозяйственных предпринимательских структур / Российское предпринимательство. 2011. № 10-1. C. $125-131$.

18. Сергиенко Е.Г., Коршикова М.В. Внедрение системы участия работников в прибыли организации как средство мотивации труда // Экономические и информационные проблемы развития региона: оценка, тенденции, перспективы. 2016. С. 240-242.

19. Ушачев И.Г. Стратегические подходы к развитию АПК России в контексте межгосударственной интеграции // АПК: экономика, управление. 2015.№ 1. С. 3-17.

20. Черникова Л.И., Гурова В.И. Сущность ресурсного потенциала предприятия // Экономические и информационные аспекты развития региона: теория и практика. Международная научно-практическая конференция. Ставропольский государственный аграрный университет. 2015. С. 257-258.

21.Эпштейн Д.Б. Темпы роста цен на импорт продовольствия и рост отечественного сельского хозяйства // Никоновские чтения. 2017. № 22. C. 45-48.

22. Agalarova E.G., Kurennaya V.V., Levushkina S.V., Miroshnichenko R.V. (2016), Program development of small and medium enterprises in Stavropol region of the Russian federation. International Journal of Economics and Financial Issues, 6(2), pp. 151-157.

23. Bannikova N.V., Baydakov A.N., Vaytsekhovskaya S.S. Identification of strategic alternatives in agribusiness // Modern Applied Science. 2015. T. 9. № 4, pp. 344-353.

24. Ivolga A.G., Levushkina S.V., Varivoda V.S., Elfimova J.M. (2017), Modeling of small and medium enterprises' sustainable development // Espacios, Vol. 38 (№33).

25. Kostyuchenko T.N., Sidorova D.V., Eremenko N.V., Chernikova L.I. Insurance as a tool for managing risks in agriculture // Mediterranean Journal of Social Sciences. 2015. T. 6. № 5, pp. 220-228. 
26. Safiullin M.R., Safiullin L.N., Samigullin I.G. Model of management of competitiveness of a machine-building complex // World Applied Sciences Journal. 2013. № 13, pp. 212-216.

\section{DATA ABOUT THE AUTHORS}

Altukhova Larisa Anatolievna, Associate Professor of Department Management, Ph.D. in Economical Science, Associate Professor

Stavropol State Agrarian University

12, Zootekhnicheskiy Str., Stavropol, Stavropol region, 355000 , Russian Federation

LarisaAlt@yandex.ru

Semko Inna Anatolievna, Associate Professor of Department Management, Ph.D. in Economical Science

Stavropol State Agrarian University

12, Zootekhnicheskiy Str., Stavropol, Stavropol region, 355000 , Russian Federation innusenka@mail.ru

\section{ДАННЫЕ ОБ АВТОРАХ}

Алтухова Лариса Анатольевна, доцент кафедры менеджмента, кандидат экономических наук, доцент

Ставропольский государственный аграрный университет пер. Зоотехнический, 12, г. Ставрополь, 355000, Российская Федераичи

LarisaAlt@yandex.ru

Семко Инна Анатольевна, доцент кафедры менеджмента, кандидат экономических наук

Ставропольский государственный аграрный университет пер. Зоотехнический, 12, г. Ставрополь, 355000, Российская Федерация innusenka@mail.ru 